\title{
Teacher reflectivity in a community of practice focusing on classroom research to improve learning with understanding in students
}

\author{
Graciela Roig $^{1}$, Antonia Rivera ${ }^{2}$ \\ ${ }^{1}$ Business Administration Department at University of Puerto Rico, Humacao Campus, Humacao, Puerto Rico \\ ${ }^{2}$ Social Work Department at University of Puerto Rico, Humacao Campus, Humacao, Puerto Rico
}

\section{Email address:}

graciela.roig@upr.edu(G. Roig), antonia.rivera@upr.edu(A.Rivera)

\section{To cite this article:}

Graciela Roig, Antonia Rivera. Teacher Reflectivity in a Community of Practice Focusing on Classroom Research to Improve Learning with Understanding in Students. Education Journal. Vol. 2, No. 4, 2013, pp. 155-162. doi: 10.11648/j.edu.20130204.18

\begin{abstract}
A community of practice focused on classroom research, used as a teacher professional development strategy, was created to promote deep reflections about student learning with understanding. This research, conducted in the southeast region of Puerto Rico, studied a community of practice in classroom research. The community of practice was formed by ten teachers who participated in an intervention geared to help them prepare a research proposal, conduct classroom research and present their findings in a professional research congress. A predominantly qualitative approach was used, mainly based on teachers' written reflections, individual interviews, focus groups, documents and observations. Results indicated that teachers considered that the environment of the community of practice promoted their own learning, encouraged them to explore new teaching strategies and assessment techniques, and achieved learning with understanding of their students. They also greatly valued the time they had to reflect over their teaching-learning practices, both individually and collectively.
\end{abstract}

Keywords: Classroom Research, Community of Practice, Professional Development, Learning with Understanding

\section{Introduction}

The importance of teacher reflection has been widely discussed as in references $[1,2]$. Forming a community of practice can be an effective environment for reflection and collaborative inquiry learning, both for students and teachers $[3,4,5,6,7,8]$. Through the community of practice, teachers can share their students' learning difficulties, assessment techniques, and appropriate teaching strategies with peers [3, 5, 9]. Many teachers are interested in improving their students' learning experience but do not have the time to reflect on this process and to share their experiences with peers to learn from each other. The community of practice addresses teachers' need by creating the conditions and the environment that leads to critical reflection in order to improve student learning with understanding. According to Etiene Wenger [10], community of practice is a group of people who engage in a process of collective learning in a shared domain of human endeavor.

Learning Science and Mathematics requires that learners develop conceptual understanding and learn adequate procedures [11]. In their report of many years of research on learning with understanding the National Center for Improving Student Learning and Achievement in Mathematics and Science (NCISLA/ Mathematics and Science) [12] explains that for students to learn with understanding, teachers should help them to connect new knowledge with prior knowledge, and construct a coherent conceptual structure. Teachers must promote student inquiry, problem solving, and validation of their ideas and procedures. To facilitate learning, teaching must provide students with opportunities to construct relationships between concepts and ideas; extend and apply knowledge; justify and explain what they know; and make knowledge their own. For this to happen, teachers should reflect on their own learning process, on students' learning difficulties, and on teaching strategies to discover the most effective ones. They also need long term professional development in their discipline content knowledge and about how students learn and think. NCISLA/Mathematics and Science promoted the development of communities of practice in order to provide an adequate environment for 
teacher reflection.

\section{Main Body}

The Puerto Rico Math and Science Partnership (PRMSP; AlACiMa for its name in Spanish), funded by National Science Foundation (NSF), was created to improve student learning with understanding (J. Arce, P.I.). It is a partnership between four campuses of the University of Puerto Rico and the Puerto Rico Department of Education [13]. One of its main components is a continuous professional development (PD) program for in-service and pre-service teachers in Science and Math to improve their conceptual knowledge and to promote student learning with understanding [14]. Following recommendations by Loucks-Horsley, Love, Stiles, Mundry \& Hewson [15], professional development activities were designed considering the way people learn, so that the teachers, as adult learners, would learn in depth and could transfer knowledge to their classroom. Teachers became part of a community of learners where they were actively engaged in inquiry activities and developed ownership of their learning process. According to Arce and Bravo [14], the Professional Development program was guided by basic principles and a clear vision of the educational process. Some of its elements are the following: (1) a safe classroom environment in which active learning and respect among participants is promoted so that participants feel free to express their doubts; (2) new knowledge is based on previous knowledge; (3) learning is continuously monitored by assessment techniques; (4) teachers use assessment results to modify future practice according to students' needs, and (5) learners and teachers reflect on their learning-teaching process. This type of reflective process would promote an effective learning environment [16].

Classroom research projects provide teachers the opportunity to study student learning problems with an active participation of the learner population $[17,18,19]$. Deep reflection is a major part of it. Classroom research differs from traditional educational research in that teachers may use the information they receive from their students immediately to modify teaching strategies to improve the student learning experience $[17,18,19,20]$.

AlACiMa aimed to motivate teachers to conduct classroom research projects to improve students' learning by forming communities of practice of teachers from different schools that would provide an appropriate environment for the reflections needed to study their own learning process and their students' learning problems. The advice of experts in the discipline of Science and Math, in assessment, and in research, was a crucial element in these communities of practice to facilitate the achievement of the stated goal.

The organizers of the community of practice researched this strategy with the following objectives: (1) to determine if the community of practice promoted the appropriate environment necessary for teachers to engage in deep reflections in studying students' learning problems and learning with understanding and (2) to evaluate the community of practice as a modality of professional development in classroom research.

This educational research was conducted in the AlACiMa Project in the Region of Humacao, located in the southeast part of the Island of Puerto Rico. Two university professors from the University of Puerto Rico at Humacao led the community of practice. In order to achieve the goals of this research, the two researchers assigned themselves different tasks: one acted as a facilitator of the intervention workshops and the second one as the evaluator of the process during the course of the intervention. Also, both worked together in the design and implementation of the research. The study was an action research in which the intervention and the research were interwoven.

To recruit and select teachers for the community of practice, a letter and a brochure were distributed among the schools in the AlACiMa project assigned to the University of Puerto Rico at Humacao. The brochure included an explanation of the concepts of community of practice and classroom research, as well as the mutual commitment of AlACiMa and participating teachers with the project. Participants were informed that they were required to assist to ten workshops of five hours each. They also had to write a research proposal and carry out a classroom research. At the end, they were required to present their results in a Congress on Educational Research sponsored by AlACiMa and to write a final report of their research. Teachers interested in participating were asked to sign an informed consent form and to fill out an application. Participant teachers received a stipend for each workshop they attended, and a certificate of participation at the end of the community of practice.

Fifteen applications were received and accepted, but only ten teachers participated throughout the entire process. All ten participants were women and lived and worked in the southeast region of Puerto Rico. Nine worked in rural schools and one in an urban school. All the schools served low socio-economic status communities. Eight of the teachers were between $46-55$ years old and the other two were younger. Eight teachers had a Bachelor degree, one was studying her master degree and the last one had a Master degree. In terms of their majors, three majored in Elementary Education (K-6), two in General Science, one in Biology, and one in Special Education and Elementary Education. The other three teachers had majors in Library Sciences, English, and Spanish, respectively. Teachers taught the following subjects: two taught all courses except English in K-3, two taught Science in $4^{\text {th }}$ to $6^{\text {th }}$ grades and one in $7^{\text {th }}$ to $9^{\text {th }}$ grades, one taught Mathematics at $7^{\text {th }}$ to $9^{\text {th }}$ grade, two taught Biology in $10^{\text {th }}$ to $12^{\text {th }}$ grade, and one taught English at K-3. The last one identified herself as a Librarian teacher in an elementary school. In terms of years of experience working in schools, two teachers reported between 11 to 15 years, three indicated between 21 to 25 years, and five reported between 26 to 30 years of service. 
Two teachers had taken a scientific research course at the university, four had taken workshops on scientific or classroom research and four indicated not having any course or workshop on research.

Multiple instruments were used to gather data in this community of practice throughout the course of the intervention to allow for triangulation in the analysis of information.

Questions were developed for individual written reflection and protocols for individual interviews, focus groups and observations. Each workshop was evaluated using a written post-activity reaction form that included quantitative and qualitative items.

The intervention in which this educational research was based was conducted from October 2006 to May 2007. Workshops were planned to provide teachers the knowledge and skills needed to conduct a classroom research projects. They included expert advice in the disciplines of Science, Mathematics, assessment, research, and technology. Data collection was carried out within the workshop sessions.

The facilitator designed ten workshops that included training in the following areas: community of practice; classroom research and learning with understanding; technology for library searches and presentations of data; assessment of learning; and writing a research report. The teachers' research process included: reflection about their teaching practices, literature review, research question, methods (including teaching strategy implemented, data collection and analysis), results and conclusions. At the end of each workshop teachers filled out a written form where they expressed what they had learned, what was not clear, and which concepts they wanted to discuss in depth in the next workshop. The workshop facilitator studied these evaluation forms and the next agenda was prepared taking into account their recommendations.

Each workshop included time for reflection on an individual, pair, triad, and group basis. All the teachers participated in two different reflection groups that could be formed: one for teachers of the same discipline (Science or Mathematics) but of different school grades and the other for teachers of the same school level (Elementary, Middle, and High School) in both disciplines. The advantage of reflecting with teachers of the same discipline in different levels was that they were able to discuss together the students' learning process in the discipline across all school levels, focusing on the learning of conceptual knowledge. On the other hand, when they reflected with teachers of the same level but from different disciplines, they were able to compare their methods and teaching strategies, and shared their successes and failures in teaching specific concepts. Each reflection provided different perspectives. Teachers were given time to discuss learning problems they encountered in their classroom and explore alternative teaching strategies to develop learning with understanding in Science and Mathematics.

\section{Results and Discussion}

In order to document the attainment of the two objectives established for this study, the researchers presented the information obtained through various means during the process of creating and sustaining the community of practice focused on classroom research.

\subsection{Reflections about Teachers' Own Learning and That of Their Students}

Various data gathering techniques were used to document the attainment of the stated objective regarding whether the community of practice promoted the appropriate environment necessary for teachers to engage in deep reflections about their own and their students' learning. They included written answers to reflective questions, individual interviews and a focus group.

Teachers were asked to reflect individually in writing about their learning process on various occasions during the course of the intervention. The first reflection was produced in the third workshop. Teachers were asked to answer two open-ended questions regarding: (1) the learning gained in the community of practice and (2) the ideas they could relate to this learning experience. Teachers reported that they had gained knowledge about the concept of community of practice, the differences between traditional educational research and classroom research, and the stages of research. They expressed that they had become aware of the importance for their research to include different sources of information and diverse means to collect data. Moreover, they stated that they had learned the pertinence for their classroom practice of the concept of learning with understanding, assessment techniques, and learning styles. Teachers also expressed in their reflections the usefulness of the mentoring received in the community of practice to conduct classroom research. Some of them stated that, for the first time, they were able to relate classroom research, assessment, and learning with understanding.

In another individual reflection, produced in the $6^{\text {th }}$ workshop, teachers were asked to reflect on their teaching strategies and student learning. Teachers were posed the following open-ended question: Did the participation in this community of practice contribute to change your teaching strategies to improve learning with understanding among your students? All teachers expressed that participation in the community of practice helped them to modify their teaching strategies to improve student learning with understanding. They expressed that they realized the need to make changes in their teaching strategies to be able to better engage their students in the teaching-learning process. One of the teachers stated that in the community of practice she acquired knowledge about a theory of cognitive development in children that helped her to improve her Science class. Other teachers informed that they were using new teaching and assessment strategies to improve their classes and to promote active participation in 
the classroom. Moreover, some teachers expressed that they became aware about the importance of reflection on the teaching-learning process and that classroom research was a means to improve student learning.

Individual interviews were carried out in the last workshop of the community of practice to document reflections about their students' learning as well as their own. It consisted of three open-ended questions: (1) How did the experience of developing a classroom research project help you to modify your teaching strategies?, (2) How did the classroom research project help you improve your understanding of the concepts of the discipline you teach?, and (3) How did you assess the learning with understanding of your students? Regarding changes in teaching strategies, teachers mentioned that they have started to use strategies like collaborative learning, teaching tools for active learning, assessment techniques, and student reflections. Teachers identified both pedagogical and science or math concepts they understand better: learning with understanding, assessment, multiple intelligences, measurement in geometry, and homogeneous and heterogeneous mixes. Concerning assessment of learning, teachers reported that they assessed student learning with understanding with observations, comic strips, questions and answers, rubrics, daily homework tasks, pre and post tests, and reflective diaries.

In the $9^{\text {th }}$ session of the community of practice, a focus group was carried out. Teachers answered the following questions: What did we achieve?, What do we still need to achieve?, How do we evaluate this experience?, Which part of the process has been the most difficult for us?, and What recommendations can we make to improve this experience? The teachers' answers relate to their own learning, their teaching practices and their student learning. All teachers expressed satisfaction because they had learned and practiced teaching strategies that they had never used before. They mentioned that their students were more interested and participated more in class because the concepts were presented in a pertinent and relevant manner that facilitated their learning. In addition, they learned that with classroom research they can measure results and modify their class to help their students' learning process. Moreover, they stated that they can now evaluate their teaching strategies and reflect on the process of teaching and learning because with this experience they have become committed to their students' learning with understanding. Finally, they affirmed that this experience has been instrumental for their own learning with understanding.

Reflection about student learning was especially evident in the research projects the teachers carried out. To focus their projects, they were asked to reflect on their students' learning difficulties and on educational strategies they could use to enhance their learning with understanding. Based on this focus, they designed and carried out their research. Table 1 presents information about these projects. The $1^{\text {st }}$. column includes the issues about their students' learning upon which teachers reflected. Moreover, all teachers identified the characteristics of learning with understanding in the students' work samples used in their research. Final reports showed that students could inquire, solve problems, and validate their ideas and procedures, construct relationships between concepts and ideas, extend and apply knowledge, justify and explain what they knew and take responsibility of their own learning process.

The ten research projects were presented in the First Congress of Educational Research sponsored by AlACiMa in April 21, 2007 at the Sheraton Hotel, San Juan, Puerto Rico. This Congress was attended by university professors and students of Education, Science and Mathematics, and school teachers from all levels.

During the academic year 2007-2008, other two communities of practice were developed as professional development strategy on classroom research in the University of Puerto Rico, one in Rio Piedras Campus and the other in Humacao Campus, using the same design and both sponsored by AlACiMa. Different aspects of these experiences were also disseminated in Spanish in several articles published in journals and publications of AlACiMa $[21,22,23,24,25,26]$.

\subsection{Community of Practice as a Professional Development Strategy on Classroom Research}

Various data gathering techniques were also used to document the attainment of the stated objective regarding evaluating the community of practice as a modality of professional development in classroom research. They included answers to reflective questions, focus group and observations of the facilitator in each session.

Nevertheless, the main evidence obtained to document the attainment of this objective was the classroom research projects planned and carried out by the participating teachers. All ten participant teachers wrote research proposals, presented their results at the First Congress of Educational Research Sponsored by AlACiMa and wrote a final report. Eight research projects were about learning with understanding on Sciences and Mathematics, whereas the other two were about using Mathematics and Sciences to promote learning of other concepts, skills, and attitudes in the students (See Table 1). Research projects of this community of practice were characterized by their diversity. They studied different educational levels, grades, subjects, themes, concepts, teaching strategies, and populations.

During the course of the intervention, additional data was obtained that reflected the teachers' views concerning the contribution of the community of practice to their professional development. On the $5^{\text {th }}$ session, teachers filled a check-list where they were asked to identify and explain the elements of the community of practice that were more useful for their professional development. The check list included the following elements: activities, individual work, working groups by discipline, working groups by school level, proposal presentations, help from peers, 
mentoring by discipline and assessment experts, recommendations of research resources, among others.

Elements identified as most helpful were: proposal presentations that allowed receiving feedback from all the participants in the community, help from peers and the working group by school level. Six teachers expressed that the proposal presentations and the help of the peers were the most helpful, whereas five teachers reported that group reflections by grade levels were very useful for them. One teacher expressed: "Listening to my peers helped me very much and allowed me to clarify my doubts. I consider that it is important to share with peers because they give us ideas and learning activities to implement in the research".

In the focus group carried out in the $9^{\text {th }}$ session, all teachers expressed their satisfaction about completing their classroom research. However, most of the teachers expressed that they still needed help in writing the findings section of their final research reports. All ten teachers evaluated the experience as outstanding. They expressed that the environment developed in the community of practice, the help received by the university professors that advised them in different areas, and the help of the peer group, were invaluable. They were very emphatic in expressing how impressed they were with the familiarity or spontaneity that existed in the community of practice. For instance, they felt no fear in contacting the advisors, either by email or by phone, or in asking questions during the workshops, and they felt that no distinctions were made among participants in the community of practice. These results suggest that they developed a feeling of solidarity and harmony that facilitated their openness, honesty, and spirit of friendship in the community of practice.

The element that all teachers mentioned as most limiting was the scarce time they had to complete the work. They expressed they needed more time for all stages of the process. Their recommendations were to have more time to complete the tasks and more workshops to deepen their knowledge.

In all meetings the research facilitator of the community of practice prepared a report with a narrative about the session, based on her observations of the process. This instrument also served to evaluate the communities of practice as a strategy for professional development. It mainly documented one of the characteristics of a good professional development program, that of responding to teacher needs [21]. The narrative included the objectives of the session, its strategies, results and factors that affected the achievement of the objectives. The research evaluator revised it to make sure everything was explained in the narrative. This document revealed that the agenda of the meetings were always modified according to the needs of the group and that in each meeting there were individual reflections, small groups and plenary reflection. These are characteristics of a community of practice [6]. The narratives also contained information about the behavior of the participants in the sessions. The analysis of this information showed that members of the group were committed to their own work as well as that of their peers' since they helped each other in every meeting, they shared constructive recommendations to improve the research designs, they offered emotional support when one member of the group needed it, and they were committed to work on their own research projects.

In each meeting participants completed a written post-activity reaction form that had both quantitative and qualitative sections. In the quantitative section there was a scale to evaluate the experience of the community of practice during a specific session. Participants had to select from 1 through 4 , where 1 meant total disagreement and 4 meant total agreement. This scale was designed by the AlACiMa Evaluation component in 2005 and adapted by the researchers. Total results obtained for all sessions were: effective organization (3.81), adequate time distribution (3.73), previous knowledge considered (3.80), learning with understanding discussed (3.81), possibility to transfer the experience to the classroom (3.82), reflection about the learning process (3.80), active participation (3.90), developing research knowledge and skills (3.76), pertinence and utility of classroom research to improve learning (3.85), usefulness of the community of practice as a modality of professional development in classroom research (3.75), usefulness of the community of practice to promote learning with understanding (3.73), opportunity for individual and collective reflections (3.85), open exchange of ideas (3.79), openness to participants' suggestions (3.81), lack of hierarchy (3.88) and solidarity (3.86). Participants expressed that the most valuable experiences were: active participation, the lack of hierarchy, solidarity, pertinence and utility of classroom research to improve learning, and individual and collective reflection.

In the qualitative section of the written report participants identified that the most valuable experiences were their reflections about their learning process, the active participation of members, and sharing their experiences. One of the teachers expressed: "In the community of practice, since it is in a group, you can analyze the themes in a different way and with the opinion of each person you can see things in a different manner..." They also mentioned the mentoring of experts and of their peers, learning by doing, rubrics workshop, and preparing their presentations on the computer. They recommended increasing the amount of time for the community of practice because they felt they needed more time in the process.

The facilitator also identified other difficulties in the intervention. Teachers needed to be continuously motivated to participate in this experience. She had to continuously use emails and phone communications to encourage participants to attend the meetings and perform their tasks on time. Another limitation encountered was that none of the participating teachers had ever conducted research themselves, although some were science teachers who 
include the scientific method as a class topic. Teachers in Puerto Rico do not usually have a formal undergraduate course of research in their professional curriculum, a limitation that the researchers were unaware of. This lack of knowledge and experience about research was a great challenge that had to be overcome in the intervention.

\section{Conclusions and Recommendations}

Based on these findings, it can be concluded that the community of practice provided teachers an appropriate environment to be involved in deep reflections, both on an individual and group basis. It allowed teachers to separate and detach from familiar or school administrative tasks and to have a space of time to reflect, inquire, create, and to innovate through their classroom research projects. The environment of solidarity, openness, trust, and relaxed communication among participants and the professional resources contributed to these reflective and active processes. These group dynamics allowed an open, honest and genuine communication that allowed participants to give and receive criticism, recommendations and acknowledgements about educational practices. The community of practice gave teachers the adequate environment to recognize mistakes and to take risks to determine the effectiveness of educational practices and to recognize what errors they had made. Nobody felt superior or inferior in this environment. Results thus evidence that, consonant with what the literature states [4, 5, 9], a community of practice can be an effective environment for reflection and collaborative inquiry.

Participants recognized that the community of practice helped them to improve their educational practices and their knowledge in assessing student learning with understanding. All teachers identified the characteristics of learning with understanding in the students work samples they used in their research. As previously stated, final reports showed that students could construct relationships between concepts and ideas, extend and apply knowledge, justify and explain what they knew and make knowledge their own.

It can also be concluded that the community of practice is an effective modality for professional development on classroom research. Teachers in the community of practice prepared research proposals, conducted the research and informed the results in oral presentations or posters in the First Congress of Educational Research sponsored by AlACiMa in San Juan, Puerto Rico in April, 2007. They all wrote a final report. However, the community of practice focusing on classroom research thus offered the opportunity for teachers not only to acquire knowledge and skills in research techniques, assessment, learning with understanding, computer technology among others, but also to critically reflect on their practice to make changes that can enhance student learning. They also developed attitudes that help them to become better persons and professional teachers. These attitudes are: respect for the diversity, tolerance, honesty, solidarity, flexibility and security in what they are doing.

Table 1. Reflection of practice and classroom research title community of practice focusing on classroom research humacao, Puerto Rico October 2006 - May 2007

\begin{tabular}{|c|c|}
\hline & \\
\hline $\begin{array}{l}\text { is abstract } \\
\text { roblems to } \\
\text { de children }\end{array}$ & $\begin{array}{l}\text { The use of pictographic maps to } \\
\text { develop learning with } \\
\text { understanding of concepts of matter } \\
\text { and its physical properties in first } \\
\text { grade students. }\end{array}$ \\
\hline $\begin{array}{l}\text { The school community generates } \\
\text { many solid wastes that can be } \\
\text { reused or recycled. }\end{array}$ & $\begin{array}{l}\text { Teaching strategies to promote } \\
\text { reflection and to encourage active } \\
\text { participation in reusing and } \\
\text { separating recyclable materials in } \\
\text { second grade students. }\end{array}$ \\
\hline $\begin{array}{l}\text { Second grade students know } \\
\text { concepts in English but have } \\
\text { difficulty and fear to participate } \\
\text { in class. }\end{array}$ & $\begin{array}{l}\text { The use of mathematics as a } \\
\text { method to motivate oral } \\
\text { presentations in the second grade } \\
\text { English class. }\end{array}$ \\
\hline $\begin{array}{l}\text { The concept of light is too } \\
\text { difficult to teach because is } \\
\text { abstract for the students. }\end{array}$ & $\begin{array}{l}\text { operative work as a teaching } \\
\text { y to promote learning with } \\
\text { tanding of the concept light } \\
\text { grade students. }\end{array}$ \\
\hline $\begin{array}{l}\text { tures is the } \\
\text { pt in the fifth }\end{array}$ & $\begin{array}{l}\text { Collaborative work as a teaching } \\
\text { strategy to promote learning with } \\
\text { understanding of the concept of } \\
\text { separation of mixtures in fifth grade } \\
\text { students. }\end{array}$ \\
\hline $\begin{array}{l}\text { Students have difficulty to learn } \\
\text { the concept of mixtures, } \\
\text { homogeneous and heterogeneous } \\
\text { mixture, independently of the } \\
\text { teaching strategy used. }\end{array}$ & $\begin{array}{l}\text { eer tutoring to promote } \\
\text { understanding of the } \\
\text { ixtures, homogeneous } \\
\text { neous mixtures in fifth } \\
\text { ts. }\end{array}$ \\
\hline $\begin{array}{l}\text { It is difficult for students with a } \\
\text { diagnosis of Mild Mental } \\
\text { Retardation to learn } \\
\text { multiplication tables. }\end{array}$ & $\begin{array}{l}\text { The use of teaching tools to } \\
\text { develop learning with } \\
\text { understanding of the concept of } \\
\text { multiplication in prevocational } \\
\text { special education students. }\end{array}$ \\
\hline $\begin{array}{l}\text { Students have problems } \\
\text { analyzing situations and writing } \\
\text { on the concept of symbiotic } \\
\text { relations. }\end{array}$ & $\begin{array}{l}\text { The development of the scientific } \\
\text { thought using analysis of situations } \\
\text { and problems with the concept of } \\
\text { symbiotic relations in seventh grade } \\
\text { students. }\end{array}$ \\
\hline $\begin{array}{l}\text { Students have difficulty to } \\
\text { understand the osmosis and } \\
\text { diffusion concepts. }\end{array}$ & $\begin{array}{l}\text { aboratory as a strategy for the } \\
\text { standing of concepts related } \\
\text { llular transportation in tenth } \\
\text { students. }\end{array}$ \\
\hline $\begin{array}{l}\text { Students in the Environmental } \\
\text { Science class have a low level of } \\
\text { thinking for their grade. Even } \\
\text { when using several teaching } \\
\text { strategies, results were not } \\
\text { favorable. }\end{array}$ & $\begin{array}{l}\text { The portfolio as a teaching strategy } \\
\text { to develop higher levels of thought } \\
\text { in studying the concept of aquatic } \\
\text { environment in twelfth grade } \\
\text { students. }\end{array}$ \\
\hline
\end{tabular}

Some recommendations evolved from this study. First, it is important to continue to use communities of practice for the professional development of teachers regarding classroom research since it is an effective vehicle for teachers to reflect about their practice and their student learning in order to enhance it. The research process is generally resisted by teachers as they considered it to be an additional task, but working in a community of practice proved to be an effective way to overcome this resistance. 
Second, a recommendation for future similar interventions arises from the difficulty encountered by teachers to perform tasks that require writing skills. It is considered necessary to add five extra sessions to dedicate at least two of them specifically to revise the literature and write the literature review section of the proposals and three to write the final report. These were the most difficult tasks confronted by teachers in the studied intervention.

Finally, it is recommended that an educational research course, especially focusing on classroom research, is included in the curriculum of teaching education. Pre-service teachers can be paired with in-service teachers to research the impact of specific educational practices in the classrooms. This course should be carried out in a community of practice environment so future teachers can benefit from a safe place in which to reflect about their teaching knowledge and practices during their formative years.

\section{References}

[1] R. Boody, "Teacher reflection as teacher change, and teacher change as moral response", Education, 128, pp. 498-506, 2008 .

[2] M.S. Cavanagh, and T. Garvey, "A professional experience learning community for pre-service secondary mathematics teachers", Australian Journal of Teacher Education, 37, pp. 56-75, 2012.

[3] D. Cesareni, F. Martini, and I. Mancini, "Building a community among teachers, researchers and university students: A blended approach to training", International Journal of Computer - Supported Collaborative Learning, 6, pp. 625-646, 2011

[4] M. Cox, "Introduction to faculty learning communities". New Directions for Teaching and Learning, 97, pp. 5-23, 2004.

[5] R. DuFour, R. DuFour, and R. Eaker, "Revisiting professional learning communities at work: Best practices for enhancing student achievements". Bloomington - IN: Solution Tree / National Education Services, 2008.

[6] M. Lunenberg, J. Loughran, K. Schildkamp, J. Beishuizen, J. Meirink, and R. Zwart, "Self-study in a community of learning researcher: What can we do to help teachers / Teacher educators benefit from our research?", European Educational Research Journal, 6, pp. 411-423, 2007.

[7] J. H. McMillan, J. Hearn, "Student self-assessment: Key to stronger student motivation and higher achievement", Educational Horizons, 87, pp.40-49, 2008.

[8] J. Seltz, "Looking back, looking forward, a focus on assessment". Leadership, 66, pp. 92-93, 2008.

[9] S. Hord, and W. Sommers, "Leading professional learning communities: Voices from research and practice", Thousand Oaks, CA: Corwin Press / National Association for Secondary Schools, 2008.
[10] E. Wenger, "Communities of practice: Learning, meaning and identity", Boston: Cambridge University Press, 1998.

[11] J. D. Bransford, A. L. Brown and R. R. Cocking, "How people learn: Brain, mind, experience, and school, Washington, DC: National Academy Press, 2000.

[12] T. P. Carpenter, M. L. Blanton, P. Cobb,M. L. Franke, J. Kaput,and K. McClain, "Scaling up innovative practices in Mathematics and Science", National Center for Improving Student Learning and Achievement in Mathematics and Science: Research Report, 2004.

[13] J. Arce, Panelist; Evidence: An Essential Tool MSP Meeting, "Using Evidence in STEM Disciplines", Washington, D.C., October 2004.

[14] J. Arce and M. Bravo, Conceptual framework for ALACiMa (PRMSP) authentic professional development program, (Unpublished manuscript), 2005.

[15] S. Loucks-Horsly, N. Love, K. Stiles, S. Mundry, and P. Hewson, "Designing professional development for teachers of science and mathematics ( $2^{\text {nd }}$ ed.)", Thousand Oaks, California: Corwin Press, 2003.

[16] K. Kiewra, "Teaching how to learn", Thousand Oaks, CA: Corwin Press, 2008.

[17] P. K. Cross, and M. Harris Steadman, "Classroom research: Implementig the scholarship of teaching", San Francisco: Jossey Bass, 1996.

[18] J. Harnett, "Reducing discrepancies between teachers'expoused theories and theories-in-use: An action research model of reflective professional development", Educational Action Research, 20, 367-384, 2012.

[19] C. Mertler, "Action research: Teachers as researchers in the classroom $\left(2^{\text {nd }}\right.$. ed.)", Thousand Oaks, California: Sage Publications, Inc., 2009.

[20] N. Fitchman, and D. Yendal-Hoppey, "The reflective educator guide to classroom research: Learning to teach and teaching to learn through practitioner inquiry". Thousand Oaks, CA: Corwin Press, 2009.

[21] G. Roig, and A. Rivera, "La comunidad de práctica como modalidad de desarrollo professional en investigación acción para el aprendizaje de conceptos científicos y matemáticos", El Sol, L, 12-13, 2008.

[22] A. Rivera \& G. Roig, (editoras) "Memorias de las Comunidades de Práctica en Investigación Acción, Año Académico 2006-2007 y 2007-2008. San Juan: Puerto Rico, 2010.

[23] G. Roig \& A. Rivera, "Conceptuación de las comunidades de práctica en la investigación acción" en Memorias de la Comunidad de Práctica en Investigación Acción, AlACiMa, San Juan: Puerto Rico, 2010.

[24] G. Roig \& A. Rivera, "La comunidad de práctica como modalidad de desarrollo profesional de maestros en Investigación Acción" en Memorias de la Comunidad de Práctica en Investigación Acción, AlACiMa, San Juan: Puerto Rico, 2010.

[25] Rivera, A. "Descripción del proceso de desarrollo de las comunidades de práctica en investigación acción: en Memorias de la Comunidad de Práctica en Investigación 
Acción, AlACiMa, San Juan: Puerto Rico, 2010.

[26] G. Roig \& A. Rivera, "La investigación acción como estrategia de evaluación de programas o proyectos" en Evaluación de Proyectos Educativos preparado por AlACiMa, San Juan: Puerto Rico, 2012. 